\title{
DETERMINATION OF THE ANGLES OF OPENING AND CLOSING GAS VALVES WHEN ORGANIZING INTERNAL MIXTURE FORMATION IN SHIP LOW-SPEED GAS-DIESEL ENGINES
}

\section{E.V. Belousov, I.V. Gritsuk, V.S. Verbovsky}

Increasing requirements for environmental indicators led to an intensification of research in the field of creating major marine engines capable of using as main gas fuel. Internal mixture formation in ship low-speed engines operating on the gas-diesel cycle can be realized at various parts of the process of air-charge compression, as a result of which the schemes of the gas-fuel supply systems can differ significantly. The duration of the compression of the gas-air mixture greatly influences the occurrence of detonation processes in the cylinder; therefore, the choice of the optimum moment for the supply of gas fuel is an important aspect when choosing the operating parameters of the gas supply system. The time at which the gas enters and the duration of its supply determine to a large extent the pressure in front of the gas valves, which, under given conditions, must ensure that a predetermined amount of gas fuel enters the working cylinder within a given time interval. The above study is devoted to determining the nature of the change in the angles of opening and closing gas valves at various pressures in front of them, taking into account the fact that the process of gas-fuel outflow under conditions of varying counterpressure is of a variable nature.

\section{ВИЗНАЧЕННЯ КУТІВ ВІДКРИТТЯ І ЗАКРИТТЯ ГАЗОВИХ КЛАПАНІВ ПРИ ОРГАНІЗАЦІЇ ВНУТРІШНЬОГО СУМІШОУТВОРЕННЯ У СУДНОВИХ МАЛООБОРОТНИХ ГАЗОДИЗЕЛЬНИХ ДВИГУНАХ \\ С.В. Білоусов, І.В. Грицук, В.С. Вербовський}

Зростання вимог до екологічних показників призвели до інтенсифікації досліджень в області створення головних суднових двигунів здатних використовувати в якості основного газові палива. Внутрішнє сумішоутворення в суднових малооборотних двигунах, що працюють по газодизельному циклу, може бути реалізовано на різних ділянках процесу стиснення повітряного заряду, в результаті чого схеми систем подачі газового палива можуть значно відрізнятися. Тривалість стиснення газо-повітряної суміші в значній мірі впливає на виникнення детонаційних процесів в робочому циліндрі, тому вибір оптимального моменту подачі газового палива $\epsilon$ важливим аспектом при виборі робочих параметрів системи подачі газу. Момент початку надходження газу і тривалість його подачі в значній мірі визначають тиск перед газовими клапанами, яке при заданих умовах має забезпечити надходження в робочий циліндр заданої кількості газового палива за заданий проміжок часу. Наведене дослідження присвячене визначенню характеру зміни кутів відкриття i закриття газових клапанів при різних тисках перед ними 3 урахуванням того, що процес витікання газового палива в умовах мінливого протитиску носить змінний характер.

\section{O.K. Kopiyka, Yu.O. Olifirenko, V. V. Kalinchak, D.S. Darakov, T.O. Fudulei, Raslavičius L. EVAPORATION OF BINARY ETHANOL-BUTANOL MIXTURE DROPLETS}

This paper presents the results of theoretical and experimental studies of individual droplets evaporation of etha$\operatorname{nol}(E)$, butanol(B) and their mixture at $60 \%$ ethanol on mass $(60 \% E+40 \% B)$ in the heated air environment in the temperature range of $350 \div 700 \mathrm{~K}$ and atmospheric pressure. The appearance of effective technologies for the synthesis of renewable fuels from biomass opens the new possibilities for the use of these alcohols as alternative fuels. In practice, alternative fuels are used as components for mixture with fossil fuels. One of the main problems of attempting to increase part of biofuel additions into mixture with transport fuels lies in difference of biofuels thermophysical properties and ones for fossil fuels. These features substantially influence on processes of drop formation and evaporation, ignition and combustion of the modified air - fuel mixture in a combustion chamber. The fuel drops evaporation as the initial stage of combustion in the engine chamber determines efficiency of all other processes. Therefore, the studies of biofuel drop evaporation and ones for their mixtures are relevant.

Theoretical modelling of drops vaporization process of these liquid biofuels mixture has been conducted by the using discreet-component approach with the system of thermo- and masstransfer equations for each component of the mixture. So, this system is including $(i+1)$ equations. For evaporation kinetics experimental study the suspended drop's method was used. There are the received dependences of the droplet current diameter and temperature on time which demonstrate the availability of the staging of the mixture evaporation. On the first stage ethanol as the liquid with lower boiling temperature evaporates more intensively. After that there is only butanol at the droplet as the liquid with higher boiling temperature. The second stage is the stationary vaporization of the leftover component of the mixture. The analysis of dependence $d^{2}(t)$ allowed to estimate duration of droplets evaporation both for singlecomponent biofuels and for their mixture. The experimental values of evaporation duration correlates with calculations data.

As is known, one of the generally accepted ways to reduce the negative impact of anthropogenic factor on the environment is the gradual replacement of fossil fuels with their renewable analogues [1]. As the last, in the segment of motor fuels, $(\mathrm{E})$ - ethanol $\left(\mathrm{C}_{2} \mathrm{H}_{5} \mathrm{OH}\right)$ is traditionally used [2]. At the same time, with the advent and improvement of new effective technologies for the synthesis of renewable fuels on the basis of biocom- 
pound, other homologues of a number of monatomic saturated alcohols, such as (B) butanol $\left(\mathrm{C}_{4} \mathrm{H}_{9} \mathrm{OH}\right)$ and its isomers [3], are becoming increasingly common and have a number of advantages over (E). But, as in the case of using (E), one of the main problems in an attempt to increase the share of biofuels in a mixture with motor fuels is the presence of a significant difference in the thermophysical properties of biofuel additives and mineral fuels, which must affect the characteristic time of droplets evaporation, formation, inflammation and combustion of the modified fuel-air mixture in the combustion chamber. Taking into account that the efficiency of fuel combustion in the engine chamber depends largely on how evaporation occurs at the initial stage, including its relatively large droplets, the study of droplet evaporation of biofuels and their binary fuel mix is definitely relevant.

Theoretical studies of liquid fuel mixture evaporation process in a heated air environment were carried out using a discrete - component approach [4], according to which a system of equations of mass - heat exchange of a fuel droplet was laid:

$$
\begin{gathered}
\dot{m}_{i}=\pi d \cdot S h \cdot \rho_{g} \cdot \varepsilon_{i} D_{i} \ln \left(1+B_{M, i}\right) ; \\
\rho_{l} c_{l} \frac{d T_{l}}{d t}=\alpha\left(T_{\infty}-T_{l}\right) \frac{S_{l}}{V_{l}}-\frac{1}{V_{l}} \sum_{i} \dot{m}_{i} L_{i}
\end{gathered}
$$

where the indices $i$ belong to the $i$-th components of the mixture,

$g, l$ - to the gas and liquid phases respectively;

$\dot{m}_{i}$ - steam flow;

$d$ - current diameter of the drop;

$S_{l}$ - current surface area of the drop;

$V_{l}$ - current volume of the drop;

$T_{l}$ - current temperature of the drop;

$D_{i}$ - coefficient of diffusion of fuel vapor in air;

$\rho_{g}$ - air density;

$L_{i}$ - specific heat of evaporation;

$\varepsilon_{i}$ - share of components in a mass flow;

$S h$ - Sherwood number;

$T_{\infty}$ - temperature of the ambient gas;

$\alpha$ - heat transfer number;

$c_{l}$ - thermal capacity of the mixture;

$B_{M, i}$ - Spalding number for mass transfer:

$$
B_{M, i}=\frac{X_{g, i, s}}{X_{l, i}-X_{g, i, s}}
$$

The vapor mass fraction of the $i$-th component near the droplet surface $X_{g, i, s}$ is determined in accordance with the Raoul law, which relates the composition of liquid mixture and vapors at its surface:

$$
X_{g, i, s}=X_{l, i} \frac{M_{i} P_{i}}{M_{l} P_{\infty}}
$$

where $M_{l}$ - the average molar mass of a liquids mixture in a drop. The saturated vapor pressure near the droplet surface is determined by the ClapeyronClausius law:

$$
P_{i}=P_{\infty} \exp \left[\frac{L_{i} M_{i}}{R}\left(\frac{1}{T_{b, i}}-\frac{1}{T_{d}}\right)\right],
$$

where $P_{\infty}$ - atmospheric pressure (1 atm),

$T_{b}$ - boiling temperature,

$T_{d}$ - droplet temperature,

$L$ - evaporation specific heat.

In the presence of a gas, flowing on a droplet, it is necessary to take into account the mass transfer due to convection. This is possible with the help of an effective Sherwood number, which makes it possible to take into account the speed of relative motion of the drop and air:

$$
S h_{1, i}=2+\frac{S h_{0, i}-2}{F_{M, i}}
$$

where $F_{M, i}-$ correction factor:

$$
F_{M, i}=\left(1+B_{M, i}\right)^{0,7} \frac{\ln \left(1+B_{M, i}\right)}{B_{M, i}},
$$

and $S h_{0, i}$-Sherwood number in the absence of evaporation:

$$
S h_{0, i}=2+0,6 \operatorname{Re}^{1 / 2} S c_{i}^{1 / 3}
$$

Then equation (1) will be:

$$
\frac{d m_{i}}{d t}=\pi d \rho_{g} S h_{1, i} X_{l, i} D_{i} \ln \left(1+B_{M, i}\right)
$$

Similarly, the convective heat transfer between the liquid and gas phases is taken into account. So, the heat transfer coefficient from the surface of the drop is equal to:

$$
\alpha=\frac{N u^{*} \lambda}{d},
$$

where $\lambda$ - the coefficient of thermal conductivity of the surrounding gas, a $\mathrm{Nu}^{*}$ - modified Nusselt criteria:

$$
N u^{*}=N u_{1} \frac{\ln \left(1+B_{T}\right)}{B_{T}} .
$$

where $B_{T}$ - Spalding heat transfer number:

$$
B_{T}=\frac{c_{p}\left(T_{\infty}-T_{d}\right)}{L} .
$$

In turn,

$$
N u_{1}=2+\frac{N u_{0}-2}{F_{T}}
$$

is analogous to $S h_{1, i}$; 


$$
F_{T}=\left(1+B_{T}\right)^{0,7} \frac{\ln \left(1+B_{T}\right)}{B_{T}}
$$

- correction factor, which is also analogous to $F_{M, i}$.

The Nusselt criteria is defined in the same way while evaporation is absent:

$$
N u_{0}=2+0,6 \operatorname{Re}^{1 / 2} \operatorname{Pr}^{1 / 3} .
$$

In addition, in the heat transfer equation, the liquid mixture specific evaporation heat, which depends on the composition by the additive law, is used: $L=\sum_{i} X_{l, i} L_{i}$

The equation system of (2) and (3) is nonlinear relatively to the solutions of the equations: the droplet temperature and the mixture components mass fractions, since the thermophysical parameters of the mixture depend on the whole. Because of this, droplet evaporation dynamics were carried out numerically using the finite difference method, taking into account the following initial conditions:

$$
t=0, R_{d}=1 \mathrm{~mm}, T_{d}=295 K, X_{g, i, s}=0 .
$$

The droplet relative velocity was assumed to be equal to $0.1 \mathrm{~m} / \mathrm{s}$. It should be noted that in the boundary case, when the concentrations of all components are equal to zero, except the one whose concentration is specifically being varied, the model gives an opportunity to get a picture of the evaporation of onecomponent fuel.

Within the framework of this model, the calculated dependences of the droplet current diameter square $d^{2}(t)$ of a binary biofuel mixture with a mass fraction (E) - 60\% against the time, were normalized to the: (i) squared droplet initial diameter $d_{0}^{2}$, for the air temperature range 440 - $675 \mathrm{~K}$ (see Fig.1a), and (ii) dependence of the droplet temperature on time (see Fig.1.b). Futher on, similar calculations for a binary mixture with a mass fraction (E) - 60\% and with a mass fraction of propanol (P) - 40\% were carried out (Fig.2).

The analysis of the data presented in Fig.1a and Fig.2a showed that the evaporation kinetics of the binary mixture droplet is basically consistent with the Sreznevsky law, except for the short-term nonlinear dependence $d^{2}(t)$ regions observed for the whole temperature range considered, and this non-linearity was expressed the more strongly, the higher the ambient temperature. The reason for this dependence $d^{2}(t)$ behavior becomes clear by comparing it with the results of modeling the dynamics of temperature changes of the same droplet during evaporation, - see Figs. $1 \mathrm{~b}$ and 2b.
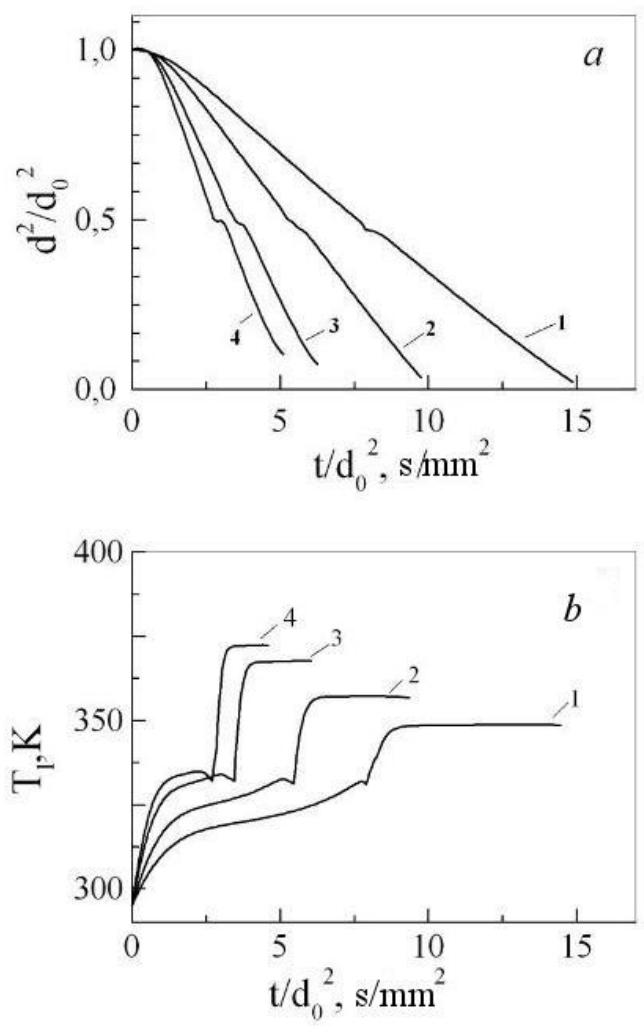

Fig.1. Evaporation kinetics of binary biofuel mixture droplets $E 60 \%+B 40 \%$

(1) $-440 K,(2)-500 K,(3)-605 K$, (4) $-675 K$.
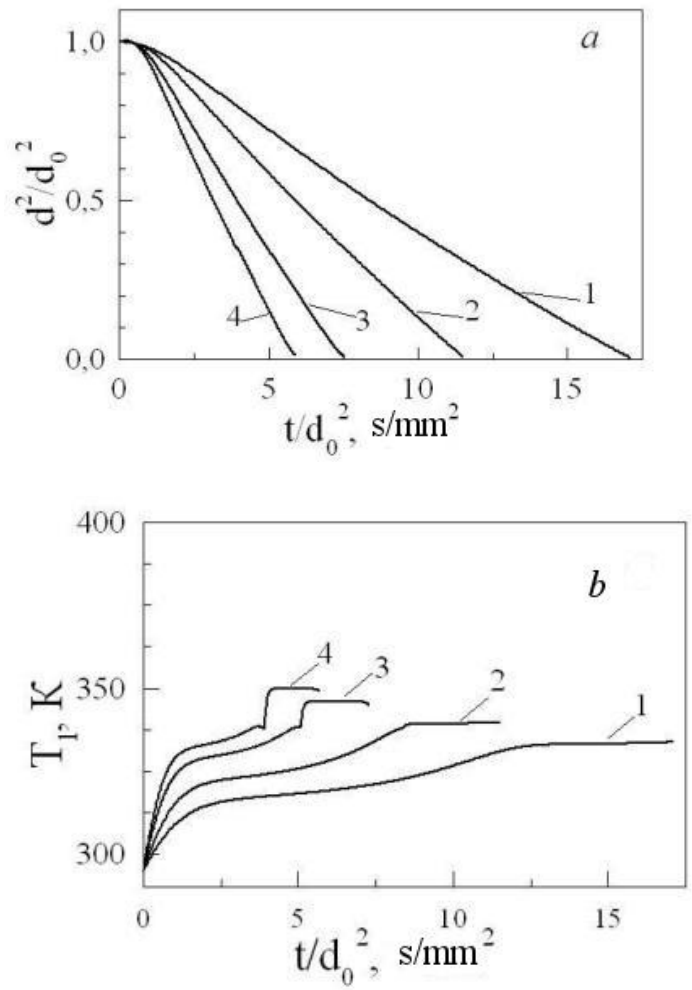

Fig.2. Evaporation kinetics of binary biofuel mixture droplets $E 60 \%+P 40 \%$

(1) $-440 K,(2)-500 K,(3)-605 K,(4)-675 K$. 
The presence of a nonlinear region $d^{2}(t)$ while $t / d_{0}^{2}<2 s / \mathrm{mm}^{2}$ can be explained by the drop heating process, and as a consequence, its thermal expansion at the beginning of evaporation. The moment of appearance of another non-linear region $d^{2}(t)$, characterized by the phenomena of subsequent droplet evaporation corresponds to the moment of a sharp increase in the droplet temperature. All this suggests the existence of a staged mechanism of evaporation of a studied biofuels binary mixture, according to which, at the initial stage, the evaporation rate of the more volatile component - (E) substantially exceeds the rate of evaporation of the less volatile component (B) of the binary mixture. And this will continue until the first component $(\mathrm{E})$ of the fuel mixture evaporates almost completely at a temperature close to its boiling point $T_{b}^{E}=351 K$. During the next stage, the drop will evaporate already as one-component, passing along all the stages consistently, including the stage of rapid heating to temperatures close to the temperature $T_{b}^{B}=390 \mathrm{~K}$, and the gradual evaporation according to the linear law.

It should be noted that for the mixture E60\% + P40\% there is no second non-linear region (see Fig. 2a), although the reheating of the drop after evaporation $(\mathrm{E})$ is present $(2 \mathrm{~b})$. This is explained by the lower difference in the boiling temperatures of the components of this mixture, and, as a result, by a smaller re-heating of the droplet after evaporation of $\mathrm{E}$ (approximately $25 \mathrm{~K}$ for a drop E60\% + P40\%, while a drop of $\mathrm{E} 60 \%+\mathrm{B} 40 \%$ warms up to $50-80 \mathrm{~K}$ ).

Experimental studies of single-component biofuel droplets evaporation kinetics $(\mathrm{E}),(\mathrm{P})$ and $(\mathrm{B})$, as well as binary mixtures $\mathrm{E} 60 \%+\mathrm{B} 40 \%$ in heated air in the temperature range $350 \div 700 \mathrm{~K}$ and atmospheric pressure were performed to check the correspondence of the obtained results to the actual course of events. The research was carried out using a suspended drop method - a drop of fuel was placed on a mobile P-shaped metal wire harness with a junction diameter of $600 \mu \mathrm{m}$. After that during $\sim 0,2$ it was placed into a heated air environment. The current fuel droplet size was determined by video capture at a frequency of $5 \mathrm{fps}$ using author's software development for capturing and processing the image. The experimental data obtained for one of the environment temperature $T_{\infty}=500 \mathrm{~K}$ is shown in Fig. 3 in comparison with the corresponding theoretical dependencies.
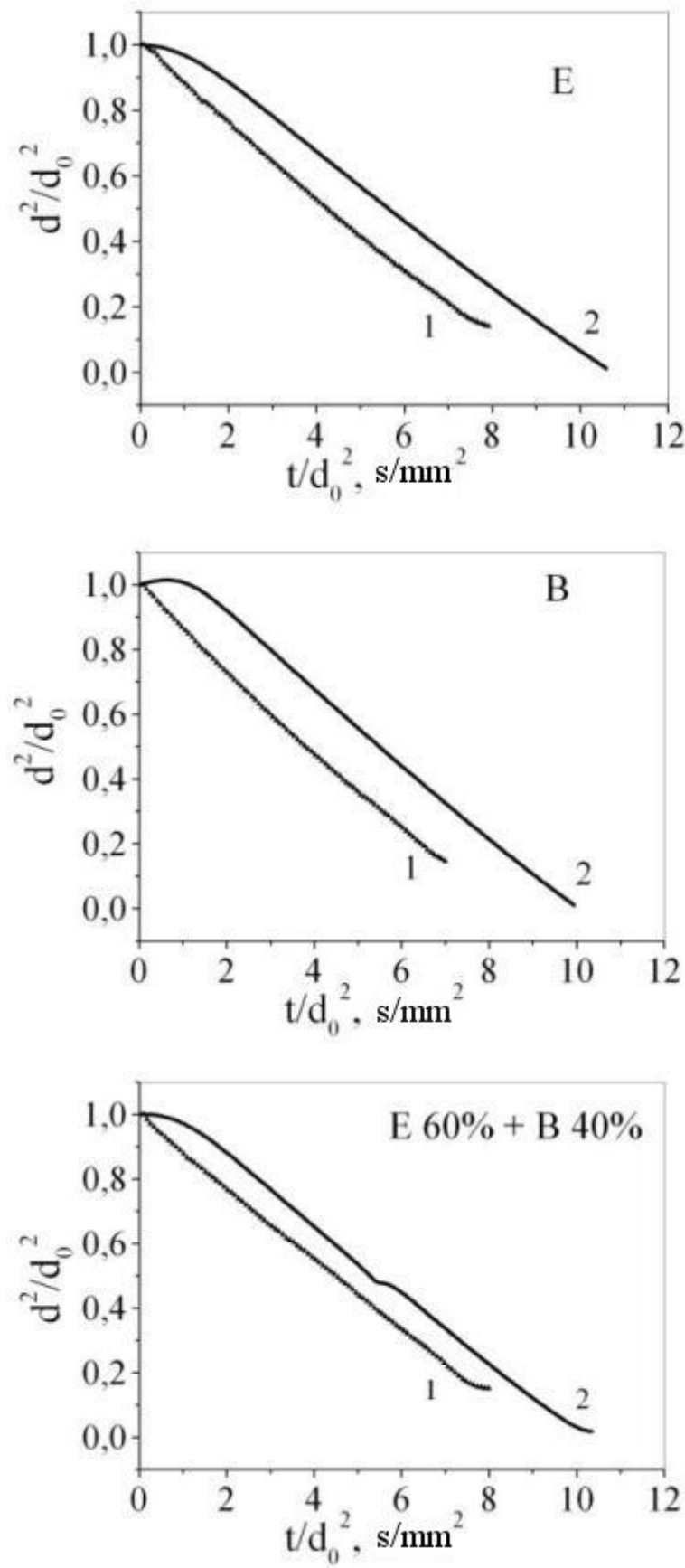

Fig. 3. Comparison of experimental data - (1) with the calculation results of the evaporation kinetics of single-component fuels $(E)$ and $(B)$ and their binary mixture $E 60 \%+B 40 \%$ - (2) at ambient temperature $T_{\infty}=500 \mathrm{~K}$.

Dependency analysis of the studied fuels allowed us to estimate the magnitude of the evaporation rate of droplets as single-component fuels and their binary mixture. As can be seen from Fig. 2, the values of the evaporating constants obtained by experimental research are sufficiently consistent with the model calculations, 
and the absence of the features (nonlinear areas $d^{2}(t)$ ) of the evaporation process of the binary mixture droplet in the experiment can be explained by the thermal influences of the suspension, which was not taken into account in the model. Certain confirmation of the existence of the revealed features of the fuel mixture droplet evaporation process can be found in [5], which presents the results of experimental studies of evaporation kinetics and the measurement of the binary mixture of ethanol and acetone with water droplets temperature. Namely, the qualitative behavior of the droplet temperature in the evaporation of water solutions with a significant (> 65-72\%) content of ethanol or acetone, and the temperature of biofuel binary mixture droplet, presented in Fig.1.b, coincides.

\section{Bibliography:}

1. Dukes J.S. Burning buried sunshine human consumption of ancient solar energy / J.S. Dukes // Climatic Change.- 2003. - V.61. - P. 31-44. 2. Gomez L.D. Sustainable liquid biofuels from biomass: the writing's on the walls / L.D.Gomez, C.G.Steele-King, S.J.McQueen-Mason // New Phytologist.-2008. - V.178, no. 3. - P. 473-485. 3. Wallner T. A Comparison of Ethanol and Butanol as Oxygenates Using a Direct-Injection, Spark-Ignition Engine / T.Wallner,
S. A.Miers and S. McConnell // Journal of Engineering for Gas Turbines and Power. - 2007. - V.131, no.3. - P. 129 139. 4. Zhang L. Vaporization modeling of petrolium-biofuel drops using a hybrid multi-component approach / L. Zhang, S-Ch. Kong. // Combustion and Flame. - 2010. - Vol. 157. Р. 2165-2174. 5. Терехов В.И. Тепломассообмен при испарении капель бинарных растворов / В.И. Терехов, Н.Е. Шишкин // Испарение, конденсачия: сб. трудов V Российской национальной конференции по теплообмену. - M., 2010. -T.4. - C.302- 305.

\section{Bibliography (translitered):}

1. Dukes, J.S., (2003), Burning buried sunshine human consumption of ancient solar energy. Climatic Change, vol.61, pp.. 31-44. 2. L.D. Gomez, C.G. Steele-King, S.J. McQueen-Mason, (2008), Sustainable liquid biofuels from biomass: the writing's on the walls. New Phytologist, vol.178, no. 3, pp. 473-485. 3. T.Wallner, S. A.Miers and S. McConnell, 2007, Comparison of Ethanol and Butanol as Oxygenates Using a Direct-Injection, Spark-Ignition Engine. Journal of Engineering for Gas Turbines and Power, vol.131, no.3, pp. 129 -139. 4. L. Zhang, S-Ch. Kong, (2010), Vaporization modeling of petrolium-biofuel drops using a hybrid multi-component approach. Combustion and Flame, vol. l57, pp. 2165-2174. 5. Terekhov, V.I., Shishkin, N.E., (2010), Teplomassoobmen pri isparenii kapel' binarnykh rastvorov [Thermoand masstransfer during evaporation of binary mixture droplets] Isparenie, kondensatsiya: sb. trudov $V$ Rossiiskoi natsional'noi konferentsii po teploobmenu, Moscow, V.4, pp.302-305.

Поступила в редакиию 15.06.2018

Копейка Александр Кузьмич - канд. физ.-мат. наук, доцент, заведующий отделом инноваций и трансфера технологий НИЧ ОНУ, Одесский национальный университет им. И.И. Мечникова, Одесса, Украина, e-mail:kopiyka@onu.edu.ua.

Олифиренко Юлия Александровна - аспирант кафедры общей и химической физики, Одесский национальный университет им. И.И.Мечникова, Одесса, Украина, e-mail: olifirenko@icn.od.ua

Калинчак Валерий Владимирович - доктор физ.-мат. наук, профессор, заведующий кафедрой теплофизики, Одесский национальный университет им. И.И.Мечникова, Одесса, Украина, e-mail: valerykalinchak@gmail.com, тел. (048) 723-12-03.

Дараков Денис Сергеевич - канд. физ.-мат. наук, старший преподаватель кафедры общей и химической физики, Одесский национальный университет им. И.И.Мечникова, Одесса, Украина, e-mail: darakov@onu.edu.ua.

Фудулей Татьяна Александровна - аспирант кафедры общей и химической физики, Одесский национальный университет им. И.И.Мечникова, Одесса, Украина, e-mail: tafudulei@ gmail.com.

Лауренсас Раславичус - доктор философии, вице-декан факультета машиностроения, Каунасский технологический университет, факультет транспортной инженерии, Каунас, Литва.

\section{ИСПАРЕНИЕ КАПЕЛЬ ДВУХКОМПОНЕНТНОЙ СМЕСИ ЭТАНОЛА И БУТАНОЛА}

\section{А.К. Копейка, Ю.А. Олифиренко, В.В. Калинчак, Д.С. Дараков, Т.А. Фудулей, Л. Раславичус}

Представлены результаты теоретических и экспериментальных исследований испарения одиночных капель этанола $(\mathrm{E})$, бутанола (В) и их смеси с массовой долей этанола $60 \%(60 \% \mathrm{E}+40 \% \mathrm{~B})$ в нагретой воздушной среде в диапазоне температур 350-700К и при атмосферном давлении. Появление эффективных технологий получения возобновляемых топлив из биомассы дало возможность использования этих спиртов как альтернативных горючих. На практике они используются как примеси к топливам, получаемым из нефти. Одна из главных проблем при увеличении доли добавок биотоплив к топливным смесям, использующимся в транспорте, заключается в отличии теплофизических свойств биотоплив от свойств минеральных топлив. Эти различия значительно влияют на процессы образования и испарения капель, воспламенение и горение модифицированной воздушно-топливной смеси в камере сгорания. Испарение капель топлива, как начальная стадия горения в камере сгорания, определяет эффективность всех остальных процессов. Поэтому немаловажно изучение испарения капель биотоплив и их смесей.

Теоретическое моделирование процесса испарения капель указанной выше биотопливной смеси проводилось с использованием приближения отдельных составляющих на основе уравнений тепломассообмена для каждого из компонентов смеси. То есть, система включает в себя (i+1) уравнение. Для экспериментального изучения кинетики испарения использовался метод подвешенной капли. Представлены полученные зависимости текущего диаметра и температуры капли от времени, которые показывают наличие стадийности испарения смеси. На первом этапе интенсивнее испаряется этанол, как жидкость с более низкой температурой кипения. После этого в капле остается только бутанол, как жидкость 
с более высокой температурой кипения. Второй этап - это равновесное испарение оставшегося компонента смеси. Анализ зависимости $d^{2}(t)$ позволяет оценить продолжительность испарения капель как для однокомпонентных биотоплив, так и для их смесей. Экспериментальные оценки длительности испарения соответствуют расчетным данным.

\title{
ВИПАРОВУВАННЯ КРАПЛИН ДВУХКОМПОНЕНТНОЇ СУМГШИ ЕТАНОЛА І БУТАНОЛА \\ О.К. Копійка, Ю.О. Оліфіренко, В.В. Калінчак, Д.С. Дараков, Т.О. Фудулей, Л. Раславичус
}

Представлені результати теоретичних і експериментальних досліджень випаровування поодиноких краплин етанолу (Е), бутанолу (В) та їх суміші з масовою часткою етанолу $60 \%(60 \% \mathrm{E}+40 \% \mathrm{~B})$ у розігрітому повітряному середовищі в діапазоні температур 350-700К та за атмосферного тиску. Поява ефективних технологій отримання поновлюваних палив з біомаси дало можливість використання цих спиртів як альтернативних палив. На практиці вони використовуются як домішки до пального, яке отримують 3 нафти. Одна 3 головних проблем при збільшенні частки домішок біопалив до паливних сумішей, які використовуються на транспорті, полягає в відмінності теплофізичних властивостей біопалив від властивостей мінеральних палив. Ці відмінності значно впливають на процеси утворення й випаровування краплин, спалахування та горіння модифікованої повітряно-паливної суміші у камері згорання. Випаровування крапель палива, як початкова стадія горіння в камері згорання, визначає ефективність усіх подальших процесів. Тому є важливим вивчення випаровування краплин біопалив та їхніх сумішей.

Теоретичне моделювання процесу випаровування краплин вказаної вище біопаливної суміші проводилося з використанням наближення окремих складових на основі рівнянь тепломасообміну для кожного з компонентів суміші. Тобто система включає в себе (i+1) рівняння. Для експериментального вивчення кінетики випаровування використовувався метод підвішеної краплини. Представлені отримані залежності поточного діаметру і температури краплини від часу, які вказують на наявність стадійності випаровування суміші. На першому етапі більш інтенсивно випаровується етанол, як рідина з нижчою температурою кипіння. Після цього в краплині залишається лише бутанол, як рідина з вищою температурою кипіння. Другий етап - це рівноважне випаровування компонента, що залишився у суміші. Аналіз залежності $d^{2}(t)$ дозволяє оцінити тривалість випаровування краплин як для однокомпонентних біопалив, так i для їх сумішей. Експериментальні оцінки тривалості випаровування відповідають даним розрахунків.

\section{А.П. Марченко, А.Ю. Федоров, О.Ю. Ліньков \\ РОЗРАХУНКОВА ОЦІНКА ТЕПЛОВІДВЕДЕННЯ ДО НАВКОЛИШНЬОГО СЕРЕДОВИЩА ТЕПЛОНОСІЯМИ СИСТЕМИ ОХОЛОДЖЕННЯ ДВЗ}

\begin{abstract}
Для визначення основних складових втрат теплоти та їх оптимізації, в роботі уточнено методику оцінки тепловиділення до навколишнього середовища теплоносіями системи охолодження в залежності від режиму роботи ДВЗ. Проведено аналітичне дослідження оцінки втрат теплоти з охолоджувальною рідиною в систему охолодження двигуна внутрішнього згоряння. За результатами побудовано апроксимовані криві зміни тепловиділення у теплоносї дизеля типу 5ТДФ в залежності від швидкісного режиму роботи та навантаження. Для розробки методики розрахунку побудовано схему енергетичного балансу силової установки транспортного засобу з двигуном типу 5ТДФ. Уточнено методику визначення складових теплового балансу. За уточненою методикою проведено розрахункове дослідження складових теплового балансу двигуна, яке дозволило визначити вплив регулювання роботи вентилятора системи охолодження на економічність дизеля при різних рівнях навантаження. Результати розрахункового дослідження дозволили визначити шляхи вдосконалення системи охолодження силової установки для підвищення ї̈ надійності за рахунок підтримки більщ стабільного температурного стану деталей ДВЗ.
\end{abstract}

\section{Актуальність}

Сучасний ДВ3 це високотехнічна і високотехнологічна система сумісно працюючих систем та механізмів. Однією з тенденцій розвитку двигунобудування $\epsilon$ відмова від втручання людини в керування роботою механізмів та систем, чи зведення такого втручання до мінімуму, тобто виключення «людського» фактору, через який трапляються надзвичайні ситуації, поломки та не ефективна робота ДВЗ. Об'єднуючи ці тенденції необхідним є визначення робочих режимів систем, що забезпечують оптимальну роботу ДВЗ. Актуальною постає задача комплексної оцінки енергетичних параметрів ДВ3 та його систем, а саме визначення втрат теплоти 3 теплоносіями системи охолодження.

\section{Мета роботи}

Уточнення методики оцінки втрати теплоти 3 теплоносіями системи охолодження в залежності від режиму роботи ДВЗ для визначення основних складових втрат теплоти та їх оптимізації. Для досягнення мети необхідно вирішити задачу розрахункової оцінки теплоти підведеної до системи охолодження, провести аналіз перспектив розвитку систем охолодження транспортних дизелів, описа- 